\title{
Professor Kalman Kovári Retires as Co-Editor of Rock Mechanics and Rock Engineering
}

Jean Sulem ${ }^{1} \cdot$ Herbert Einstein $^{2} \cdot$ Mariacristina Bonini $^{3}$

Published online: 13 June 2020

(C) Springer-Verlag GmbH Austria, part of Springer Nature 2020

Professor Kovári had already expressed his wish to retire as Co-Editor in discussions with Giovanni Barla last year but then stayed on to help bridge the transition in the editorial leadership. Now that the new editorship is in place, he decided to permanently step down. Professor Kovári became the "Editor" effectively the "Editor in chief" in 1982. Up to this point in time the journal had evolved from a journal mostly for Austrian professionals to the official journal of the International Society for Rock Mechanics. This history is reflected in the names of the journal: Geologie und Bauwesen 1929-1962, Rock Mechanics and Engineering Geology-Felsmechanik und Ingenieurgeologie 1963-1969, Rock Mechanics-Felsmechanik-Méchanique des Roches 1969-1982. When Professor Kovári took over he changed the name to "Rock Mechanics and Rock Engineering". This was done to emphasize the importance of practice. This name change was reflected well by the composition of the new Editorial board and the acquisition and selection of papers. Clearly, this was helped by the fact that
Professor Kovári combined his broad research activities with work in the international rock engineering praxis. Later on ISRM similarly changed its name with the inclusion of "engineering".

In 2001 Professor Kovári asked Professor Barla to take over as editor while he and Herbert Einstein were Co-Editors. This "triumvirate" made important editorial decisions to maintain the quality of the journal while being involved in the day-to-day running of the journal through participation in the review process. In both roles we could always count on Professor Kovári's thoughtful comments. We can certainly say that the journal would not be what it is if he had not been Editor and Co-editor.

THANK YOU KALMAN KOVÁRI

Publisher's Note Springer Nature remains neutral with regard to jurisdictional claims in published maps and institutional affiliations.

Mariacristina Bonini

rmre.ae@gmail.com

Paris, France

2 Cambridge, MA, USA

3 Turin, Italy 